\title{
CHEMICAL PESTICIDES AND VEGETAL EXTRACTS ON Sitophilus zeamais CONTROL IN STORED CORN GRAINS
}

\author{
INSETICIDAS QUÍMICOS E EXTRATOS VEGETAIS NO CONTROLE DE \\ Sitophilus zeamais EM GRÃOS DE MILHO ARMAZENADOS
}

\begin{abstract}
Marcella Karoline Cardoso VILARINHO' ${ }^{1}$; Tonny José Araújo da SILVA²; Carlos CANEPPELE ${ }^{3}$; Adriano Ferreira ROZADO

1. Professora Mestre do curso de Agronomia, Universidade do Estado de Mato Grosso - UNEMAT, Cáceres, MT, Brasil. marcellakarolinecv@ @otmail.com; 2. Professor Doutor do Programa de Pós Graduação em Engenharia Agrícola (ICAT/UFMT), Universidade Federal de Mato Grosso - UFMT, Rondonópolis, MT, Brasil; 3. Professor Doutor do Núcleo de Tecnologia em Armazenagem (NAT/UFMT) da Faculdade de Agronomia e Medicina Veterinária - UFMT, Cuiabá, MT, Brasil; 4. Professor, Doutor, ICAT - UFMT, Rondonópolis, MT, Brasil.
\end{abstract}

\begin{abstract}
Sitophilus species are major pests of stored grain and their control is achieved mainly with the use of chemical insecticides, but the indiscriminate use of these products is resulting in several undesirable factors to man and to the environment. Thus, the use of natural insecticides comes as an option to control the insects, while lessening risks to the environment. The study was conducted at the Institute of Agricultural Sciences and Technologies, Rondonópolis campus of the Federal University of Mato Grosso, in the period from March to September 2012. The experiment was conducted under three different storing conditions. Aqueous extracts were obtained by the addition of Allium sativum L, Azadirachta indica A. Juss. and Cymbopogon winterianum Jowitt vegetable powders in distilled water, at a ratio of $5 \mathrm{~g}$ per $100 \mathrm{ml}$, and the levels of chemical insecticides were of 0.04 and $0.15 \mathrm{ml} / 100 \mathrm{ml}$ of water for deltamethrin and chlorpyrifos, respectively. Treatments were added to the corn grains, which were placed in a $2.5 \mathrm{~L}$ glass container, mixed by manual shaking and infested with 20 adults of unsexed Sitophilus zeamais. Grains were stored for 60 days. At 30 and 60 days, the following items were analyzed: bugs count, water content in grains and electrical conductivity. The data were submitted to analysis of variance, and means were compared by Tukey test at 5\% probability. At 30 days, the efficiency of chemical insecticides in the control of Sitophilus zeamais was observed in the three storage environments. Vegetal extracts were not effective in controlling insects. The larger number of insects increased the electrical conductivity and humidity values in the grains.
\end{abstract}

KEYWORDS: Insect. Temperature. Humidity.

\section{INTRODUCTION}

Corn is a high economic and social expression agricultural product which is considered the culture that has the largest genetic characterization between arable species, and its raw material is used in human and animal feeding, as well as in industrial production of byproducts ranging from starch, oil and flour to animal feeds (GUIMARÃES, 2007).

Being a culture of good adaptation to different ecosystems, Brazil is a country with high potential in the production of this grain, and in numbers the 2011/2012 harvest was estimated at 165.92 million tons, 3.12 million more tons in relation to the previous year harvest. Of this amount, Mato Grosso state was responsible for the production of 40.223 million tons (Conab, 2012).

Due to necessity to increase the productivity of this cereal, different technologies have been employed in the field with the aim of reducing losses in cultivation, and at this stage there is a need to focus on improvements in the collection and storage of the product processes, once that the grain has favorable characteristics for storing for a long period of time without any loss in quality. However, in order to obtain success during storage, proper cleaning, drying and grain storage practices are needed. Thus, it is important to be careful with factors that affect the grain during this stage, and among them, the largest loss-causing factors are: high temperature and humidity values at the time of storage, carbon dioxide and oxygen concentration in the interstitial air, grain characteristics, presence of microorganisms, insects and mites, and lack of structure in storage units.

The preservation of this cereal quality is also greatly influenced by the presence of insects, particularly in tropical places, which have ideal characteristics for their development in grains (FARONI et al., 2005). Furthermore, storage pests have undergone adaptations to survive in different environments, what complicates their control. Pests cause losses in storage and generate weight loss, 
increases in the respiratory activity of the grains and heating of the infestation site when consuming grains, resulting in the appearance of fungi, and thus resulting in higher losses of dry matter, depreciating grain quality.

In Brazil, Sitophilus zeamais Mots., 1855 (Coleoptera, Curculionidae) corn weevil has caused many quantitative and qualitative damage to corn culture, especially during storage (CANEPPELE et al., 2003;), and it stands out as the most important pest of stored grains in Brazil, and for having a high biotic potential and a large number of hosts, its control must be done effectively (CERUTI; LAZZARI, 2005).

The maintenance of grains and seeds sanitary quality is made basically through the control of insect pests associated with stored grain, through the extensive use of chemicals. However, the indiscriminate use of this practice, coupled with the scarcity of products registered for this purpose, what hinders the rotation of chemical groups, has caused resistance in several insects' species, presence of residues in food and poisoning of operators.

These and other factors have been driven new research for less harmful alternatives to men and the environment, and among them there is the alternative control through plant origin insecticides, which has as main advantages the minimization of environmental problems, of residues in food, of harmful effects on beneficial organisms, of insect resistance to insecticides, and the reduction of human poisoning.

Research with insecticide plants are carried out in order to find molecules with insecticides activities that may allow the synthesis of new products, and also in order to do the direct use of these plants in the control of insect pests. Even with the economic and conservation benefits of stored products offered by chemical insecticides against storage pests, the incorporation of sustainable use practices and the rational use of resources from biodiversity can become a difference that is capable of generating competitive advantages.

Considering the economic importance of corn, its physiological characteristics and problems with stored grain pests, this study evaluated the insecticide effect of aqueous vegetal extracts and chemical insecticides commonly used to control grain pests stored in different storage conditions.

\section{MATERIAL AND METHODS}

The test to evaluate the insecticide potential of chemicals and plant extracts in different storage conditions was conducted at the Institute of Agricultural Sciences and Technologies, Rondonópolis campus of the Federal University of Mato Grosso, in the period from March to August 2012.

The treatments were conducted under three storage conditions, and to achieve the goal of this research, controlled chambers that are similar to an entomotron were made, which turned possible the implementation of the experiment under the desired conditions (Figure 1). The materials used in their construction were wooden boards, thermal insulation, temperature sensors and psychrometers. For the chamber construction, a structure containing three shelves with of $0.66 \times 1.60 \mathrm{~m}$ dimensions and closed with doors made of wood and polystyrene plates was used, thereby forming insulation, in order to maintain the temperature and humidity of the controlled environments always constant.

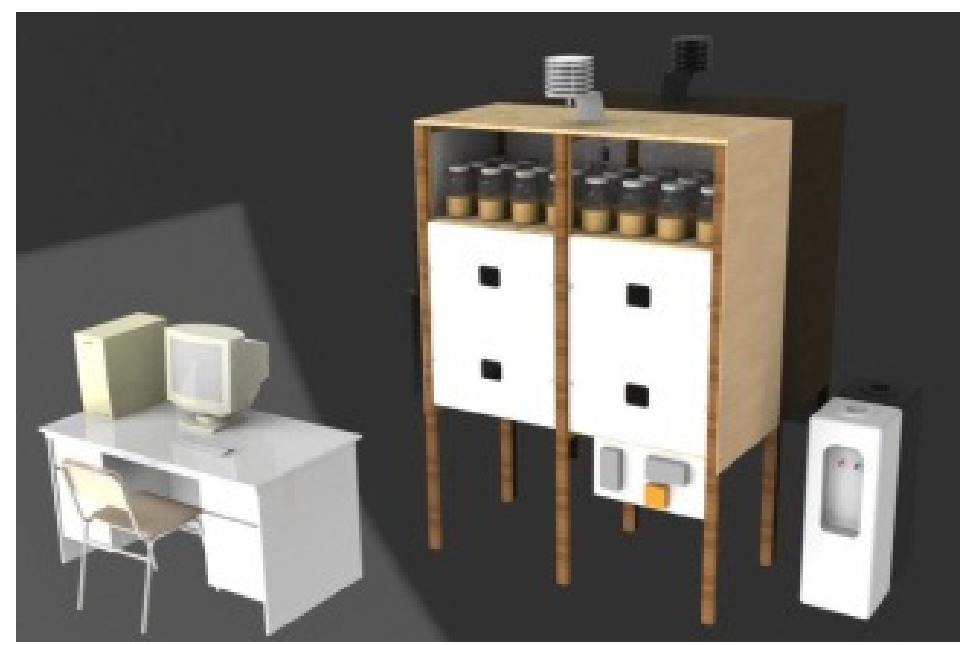

Figure 1. Schematic drawing of the storage chamber (Entomotron). (Illustration: Provided by the author). 
The experiment consisted of three environments: AI- temperature and humidity; AIIhumidity control; and AIII- humidity and temperature control. To control the temperature, a cooling and heating system was built, which were triggered automatically if the temperature exceeded certain determined extremes.

Humidity control was accomplished through a recipient containing silica with forced air circulation. Within each environment a psychrometric set was installed, consisting of thermocouples sensors connected to a data logger, CR1000 model, which had the function of storing data and automating the heating, cooling and humidity control systems. The temperature maintained in AIII environment was of $25.1{ }^{\circ} \mathrm{C}$, with a relative humidity of $70 \%$ (mean values), with the last variable also maintained in the AII environment.

The insects used in the experiment were created at the postharvest laboratory of the Institute of Agricultural Sciences and Technologies, Rondonópolis campus of the Federal University of Mato Grosso. They were kept in glass recipients with $2.5 \mathrm{~L}$ capacity, with the lid sealed with light type fabric (voile) and rubberized material (EVA) on the sides, thus avoiding insects leaving. Corn grains filling up to the middle of the recipient were used as substrate for the maintenance and creation of the insects. They were kept on shelves and in uncontrolled environmental conditions.

Glasses maintenance was made throughout the experiment, where on an average of every 60 days the adults of $S$. zeamais were transported to clean recipients with a new grain mass. The insects used for the experiment had an average age of 42 days.

Regarding the choice of chemicals used to S. zeamais control, it was opted for the use of deltamethrin, which is an active ingredient currently registered and used for the control of this insect. Taking the purpose of comparing another active ingredient, (Chlorpyrifos) was also used, which according to research has shown efficiency in the control of storage pests (SMIDERLE; CICERO, 1998). The doses were of 0.04 and $0.15 \mathrm{ml} / 100 \mathrm{ml}$ of water for deltamethrin and chlorpyrifos, respectively (ALFONSO et al., 2005).

The extracts were obtained from neem (Azadirachta indica A. Juss) and citronella (Cymbopogon winterianum Jowitt.) leaves and from garlic cloves (Allium sativum L). These plant species were chosen species due to scientific references of their use as insecticides. To prepare the extracts, the collected plant structures were dried in an oven with air circulation at $40{ }^{\circ} \mathrm{C}$ for $48 \mathrm{~h}$, and only garlic cloves needed a longer dehydration period $(72 \mathrm{~h})$.

After triturated, vegetable powders were stored separately in airtight recipients until its use. Aqueous extracts were obtained by the addition of the vegetable powders in distilled water at a ratio of $5 \mathrm{~g}$ per $100 \mathrm{ml}$.

Mixtures were maintained in sealed flasks for $24 \mathrm{~h}$ for the extraction of water soluble compounds, and after this period were filtered through fine fabric (voile), obtaining the 5\% aqueous extracts (BRUNHEROTTO et al., 2010).

\section{Experiment installation:}

Initially, the grain mass was sieved on a 4 $\mathrm{mm}$ mesh, for waste removal, and subsequently mixed in a 08 CFW 08 model homogenizer, for samples standardization. Twenty samples of approximately $50 \mathrm{~g}$ were taken to determine the water content of the grains by the oven method at $103{ }^{\circ} \mathrm{C} \pm 1{ }^{\circ} \mathrm{C}$ for $72 \mathrm{~h}$, and it was found that the grain mass showed a $12 \%$ water content.

Each experimental unit consisted of glass recipients with $2.5 \mathrm{~L}$ capacity, containing $1 \mathrm{~kg}$ of corn grains that were previously exposed to a temperature of $-18^{\circ} \mathrm{C}$ for five days in a domestic freezer, in order to eliminate contaminant insects. Treatments applied in the experiment installation were distributed into the recipients and mixed by hand shaking up to their uniformization, with the excess being removed to prevent further concentration of the product in certain points.

After the treatments application, each experimental unit was infested with 20 adults of unsexed Sitophilus zeamais. The experiment was conducted without insect reinfestation. The grains were stored for a period of 60 days. The variables were analyzed every thirty days from the experiment installation, totaling two evaluation periods (30 and 60 days). The choice of the amount of grains used for each experimental plot was made according to the need to withdraw samples for testing grains water content and electrical conductivity in each evaluation period.

The experiment installed on June 8, 2012, was composed of six treatments, entered into three storage environments, with four repetitions, totaling 72 plots. The two months prior to the beginning of the experiment (March to May 2012), were destined for the construction and automation of the storage chambers (entomotron). The variables analyzed were:

Insect Count: In order to evaluate the products insecticide efficiency, live and dead insects 
were separated with the aid of a sieve. After the first evaluation, living insects were returned to have their development observed in the next assessment.

Water content in the grains: To determine the water content in grains, approximately $50 \mathrm{~g}$ of corn grains were taken from each plot. The water content was determined in both evaluation periods, using the standard oven method at $103{ }^{\circ} \mathrm{C} \pm 1{ }^{\circ} \mathrm{C}$ for 72 hours, which was adopted by the Asae (1992) standard. This methodology was measured according to Karl Fischer titration, which is considered a basic reference standard (Grabe, 1987).

Electrical conductivity: During the storage period, tests were conducted in four subsamples of 50 grains for replicates of each treatment. Each subsample was weighed on a $0.01 \mathrm{~g}$ precision balance and placed in plastic cups of $180 \mathrm{ml}$, to which $75 \mathrm{ml}$ of deionized water was added. The samples were kept at $25^{\circ} \mathrm{C}$ in a climatic chamber (BOD) for 24 hours. After this period, the samples were shaken for homogenization of the exudates released into the water. The readings were made in an electrical conductivity meter mCA 150 model made by Ms Tecnopon, which was previously calibrated with a standard solution of sodium chloride with known conductivity value and an electrode of $1 \mu \mathrm{S} \mathrm{cm} \mathrm{cm}^{-1}$ constant. Before and after each determination, the electrode was repeatedly washed with deionized water. The value of the electrical conductivity read by the device was divided by the weight of its respective sample of 50 grains in grams and the value expressed in $\mu \mathrm{S} \mathrm{cm}^{-1}$. $\mathrm{g}^{-1}$, as described by Vieira (1994).

The experimental design was of subdivided plots in a factorial design with six treatments, three settings and four replications. Analysis of variance was performed for each period of evaluation of the variables, and means were compared by Tukey test at 5\% probability, using the SISVAR statistical program (FERREIRA, 2012).

\section{RESULTS AND DISCUSSION}

The results show that in all settings the chlorpyrifos chemical insecticide showed significant efficiency in Sitophilus zeamais control, being $100 \%$ effective in killing the insects in the first evaluation period (30 days) (Table 1). Due to the maximum mortality effect of chlorpyrifos in the first period, no statistical analyzes of this variable were made for all 60 days of evaluations because there was no living insects. These results agree with Afonso et al. (2005), who using the same dose of chlorpyrifos insecticide in Sitophilus zeamais observed the control of $100 \%$ of the insects after 96 hours of contact with the insecticide.

Table 1. Number of dead insects at 30 and 60 days after the start of treatments, in the three studied settings. ${ }^{(1)}$

\begin{tabular}{|c|c|c|c|c|c|c|c|c|c|c|c|c|}
\hline \multirow{4}{*}{$\begin{array}{c}\text { Insecticides } \\
\\
\text { Garlic }\end{array}$} & \multicolumn{12}{|c|}{ Settings $^{(2)}$} \\
\hline & \multicolumn{6}{|c|}{30 days } & \multicolumn{6}{|c|}{60 days } \\
\hline & \multicolumn{2}{|c|}{ I } & \multicolumn{2}{|c|}{ II } & \multicolumn{2}{|c|}{ III } & \multicolumn{2}{|c|}{ I } & \multicolumn{2}{|c|}{ II } & \multicolumn{2}{|c|}{ III } \\
\hline & 6.0 & $\mathrm{aB}$ & 5.5 & $\mathrm{aC}$ & 4.2 & $\mathrm{aC}$ & 6.2 & $\mathrm{aAB}$ & 5.7 & $\mathrm{aA}$ & 9.0 & $\mathrm{aB}$ \\
\hline Citronella & 7.7 & $\mathrm{aB}$ & 4.5 & $\mathrm{aC}$ & 8.2 & $\mathrm{aBC}$ & 4.2 & $\mathrm{bAB}$ & 7.5 & $\mathrm{bA}$ & 27.5 & $\mathrm{aA}$ \\
\hline Chlorpyrifos & 20.0 & $\mathrm{aA}$ & 20.0 & $\mathrm{aA}$ & 20.0 & $\mathrm{aA}$ & - & - & - & - & - & - \\
\hline Deltamethrin & 15.2 & $\mathrm{aA}$ & 11.0 & $\mathrm{abB}$ & 10.5 & $\mathrm{bB}$ & 1.0 & $\mathrm{aB}$ & 4.7 & $\mathrm{aA}$ & 5.7 & $\mathrm{aB}$ \\
\hline Neem & 6.5 & $\mathrm{aB}$ & 4.5 & $\mathrm{aC}$ & 6.5 & $\mathrm{aBC}$ & 15.2 & $\mathrm{aA}$ & 10.0 & $\mathrm{aA}$ & 15.7 & $\mathrm{aAB}$ \\
\hline Control & 4.5 & $\mathrm{aB}$ & 3.5 & $\mathrm{aC}$ & 4.5 & $\mathrm{aC}$ & 4.0 & $\mathrm{aAB}$ & 7.5 & $\mathrm{aA}$ & 11.2 & $\mathrm{aB}$ \\
\hline
\end{tabular}

Data of this study also revealed the statistical equality of deltamethrin treatment in the setting I, after thirty days of storage where there was no humidity and temperature control, and in the 
setting II, after 60 days of storage with humidity control in an average of $70 \%$ and ambient temperature, which was efficient in insects killing like chlorpyrifos. Pereira et al. (2003), working with barley stored grains, also verified deltamethrin efficacy in Sitophilus oryzae mortality until the thirtieth day of storage, although Lahóz (2008) had not seen the expected efficiency in the control of Sitophilus zeamais in stored corn from the beginning of assessments. Treatments based on vegetal extracts have not statistically differed among them and the control in the first evaluation period, with lower efficiency in control compared to chemical insecticides. In the second evaluation period, no statistical differences between the vegetal extracts and the control were observed, where the largest numbers of dead insects were observed in the neem on setting I and in garlic, neem and control on setting II.

Considering the number of live insects, the best treatment, i.e., the one that left fewer offspring after chlorpyrifos, was deltamethrin at 30 days in the setting II and at 60 days in all settings (Table 2). Analyzing these results, it was found that all treatments had birth rates from the second evaluation period, showing statistical equality between vegetal extracts treatments and the control, where the highest incidence of live insects were observed in garlic treatments on settings I and III, and neem and citronella on settings I and II, respectively, strengthening the hypothesis that the mortality of insects in the last period has been from natural causes.

It can also be inferred that the absence of insecticidal activity of vegetal extracts may be due to low concentration and the extraction method used in the study. Unlike the results found in this study, Coitinho et al. (2006), using Neem essential oil, had the lowest incidence of insects between the employed treatments, and this may have occurred because authors worked with higher doses $(50 \mathrm{ml} / 20 \mathrm{~g})$ than those used in this study.

Table 2. Number of living insects at 30 and 60 days after the start of treatments, in the three studied settings. ${ }^{(1)}$

Insecticides

Settings ${ }^{(2)}$

\section{0 days}

I

II
$14.5 \quad \mathrm{aC}$

$15.7 \mathrm{aC}$

$11.7 \quad \mathrm{aBC}$

$15.5 \mathrm{aC}$

$0.0 \quad \mathrm{aA}$

$0.0 \quad \mathrm{aA}$

Deltamethrin

$4.7 \quad \mathrm{aA}$

$9.0 \mathrm{abB}$

$9.5 \mathrm{bB}$

$84.0 \quad \mathrm{aA}$

$83.7 \quad$ aA

75.5 aA

Neem

$13.5 \quad \mathrm{aB}$

$15.7 \mathrm{aC}$

$13.5 \mathrm{aBC}$

$568.0 \quad \mathrm{aB}$

$355.5 \quad \mathrm{aAB}$

$394.0 \quad \mathrm{aAB}$

Control

\author{
$15.5 \mathrm{aB}$
}

$16.5 \mathrm{aC}$

$15.5 \mathrm{aC}$

$425.2 \mathrm{aAB}$

365.2 aAB

$377.0 \quad \mathrm{aAB}$

${ }^{(1)}$ Means followed by the same letter, lowercase in lines or uppercase in columns, do not differ by Tukey test at 5\% probability. ${ }^{(2)} \mathrm{I}-$ Temperature and Relative Humidity: Setting; II - Temperature: Setting; Average humidity: 70\%; III - Average Temperature: $25.1^{\circ} \mathrm{C}$; Average humidity: $70 \%$. Mean values throughout the storage period.

In addition, the setting temperature may have been of great influence on the further development of these insects, because according to Caneppele et al. (2010), the optimum temperature for $S$. zeamais development is between $28{ }^{\circ} \mathrm{C}$, although its development also occurs between 15 and $34^{\circ} \mathrm{C}$, thus being consistent with the temperature values of the study settings, which range from 24.6 to $27.6^{\circ} \mathrm{C}$ from the first to the last evaluation period. Another way to explain that natural insecticides have not presented efficiency may be related to the method of extracts extraction, thus agreeing with Tavares and Vendramim (2005), which have also found no insecticidal effect of aqueous vegetal extracts in relation to $S$. zeamais adults. According to Tavares (2006), compounds with insecticidal activity present in some plants cannot be extracted in high polarity solvents, which 
is the opposite when these are of medium or low polarity (chloroform and hexane).

For water content in the grains in different treatments, it was observed that at 30 and 60 days, in general, there was no difference between settings or between treatments, except for deltamethrin in setting III at 30 days, which showed high grain humidity content (18.6\%) (Table 3 ). It is noted that from the first to the last assessment period there was a decrease in the water content of the grains in the treatments with deltamethrin and chlorpyrifos.

Table 3. Humidity $(\%)$ at 30 and 60 days after the start of treatment, in the three settings. ${ }^{(1)}$

\begin{tabular}{|c|c|c|c|c|c|c|c|c|c|c|c|c|}
\hline Insecticides & \multicolumn{12}{|c|}{ Settings ${ }^{(2)}$} \\
\hline & \multicolumn{6}{|c|}{30 days } & \multicolumn{6}{|c|}{60 days } \\
\hline & \multicolumn{2}{|c|}{ I } & \multicolumn{2}{|c|}{ II } & \multicolumn{2}{|c|}{ III } & \multicolumn{2}{|c|}{ I } & \multicolumn{2}{|c|}{ II } & \multicolumn{2}{|c|}{ III } \\
\hline Garlic & 15.6 & $\mathrm{aA}$ & 14.9 & $\mathrm{aA}$ & 15.6 & $\mathrm{aA}$ & 15.1 & $\mathrm{aAB}$ & 14.9 & $\mathrm{aAB}$ & 14.5 & $\mathrm{aA}$ \\
\hline Citronella & 17.3 & $\mathrm{abAB}$ & 16.3 & $\mathrm{aA}$ & 18.1 & $\mathrm{bB}$ & 16.3 & $\mathrm{aB}$ & 16.2 & $\mathrm{aAB}$ & 17.4 & $\mathrm{aB}$ \\
\hline Chlorpyrifos & 17.9 & $\mathrm{aB}$ & 19.0 & $\mathrm{aB}$ & 18.3 & $\mathrm{aB}$ & 14.8 & $\mathrm{aAB}$ & 16.6 & $\mathrm{bB}$ & 15.0 & $\mathrm{abA}$ \\
\hline Deltamethrin & 16.8 & $\mathrm{bAB}$ & 15.0 & $\mathrm{aA}$ & 18.6 & $\mathrm{cB}$ & 14.0 & $\mathrm{aA}$ & 14.0 & $\mathrm{aA}$ & 16.0 & $\mathrm{bAB}$ \\
\hline Neem & 16.8 & $\mathrm{abAB}$ & 15.8 & $\mathrm{aA}$ & 18.1 & bB & 16.1 & $\mathrm{abAB}$ & 15.1 & $\mathrm{aAB}$ & 17.6 & $\mathrm{bB}$ \\
\hline Control & 16.4 & $\mathrm{aAB}$ & 15.2 & aA & 15.9 & $\mathrm{aA}$ & 15.4 & $\mathrm{aAB}$ & 14.6 & $\mathrm{aAB}$ & 16.0 & $\mathrm{aAB}$ \\
\hline
\end{tabular}

(1) Means followed by the same letter, lowercase in lines or uppercase in columns, do not differ by Tukey test at 5\% probability. ${ }^{(2)} \mathrm{I}$ Temperature and Relative Humidity: Setting; II - Temperature: Setting; Average humidity: $70 \%$; III - Average Temperature: $25.1^{\circ} \mathrm{C}$; Average humidity: $70 \%$. Mean values throughout the storage period.

From the initial period until the end, settings humidity was of around $75.8 ; 73.9$ and $72.6 \%$, and temperature was of $24.4 ; 25.0$ and $24.7{ }^{\circ} \mathrm{C}$ on settings I, II and III, respectively. These data are in agreement with those of Alves et al. (2008), who studied the influence of $S$. zeamais in the respiratory rate of corn grains during a storage period of 150 days and observed a decrease in humidity, with an increase in the temperature and the storage period, and with Faroni et al. (2005), who also observed a decrease in the water content of corn grains in temperatures above $25{ }^{\circ} \mathrm{C}$. In the two abovementioned papers, the authors agree that the reduction of grain moisture is caused by the high temperatures of the environment in which the grains are stored.

Considering the lowest grain moisture content at 60 days for the deltamethrin treatment, when compared to the control content (Table 3) and when related to the lowest values of live insects (Table 2), it can be inferred that the low grain moisture may have been a positive factor for the efficiency of deltamethrin, confirming what has been described by Samson et al. (1988), who reported that insecticides are more stable when in contact with grains with lower humidity content. Lahóz (2008) had also observed this effect when working with insecticides in S. zeamais control and added that the low grain moisture decreases oviposition of insects.

Another factor that may have influenced the low water content in the grains was the amount of live insects in the treatments with chemical insecticides, as it is observed in Table 2 that chlorpyrifos and deltamethrin were the treatments that had the lowest index numbers of insects alive. According to Alves et al. (2008), increases in the moisture content are caused by increases in the population growth rate of pest insects, which produces water through their metabolism, contributing to the increase in the water content in grains. As population growth was reduced in these treatments, the respiratory rate of the insects was not high, so the effect on the moisture content was also reduced.

This effect of insects on the grain moisture can be confirmed by the observation of vegetal extracts treatments and the control, which had a 
high rate of population growth from the second evaluation period, as well as high water content in grains. This information is confirmed by Silva et al. (2003) and Antunes et al. (2011), who observed that an increase in humidity of wheat and corn grains as $S$. zeamais population increased, further reinforcing the hypothesis that insects have influence on the increase in grain moisture content.

In the first period, the moisture values that were high may have suffered interference from the environment and the initial period of storage, tending to the hygroscopic equilibrium of plots with settings. On this occasion, air relative humidity (75.7, 67.2 and $69.4 \%$ on average) and temperature values (average of $24.6,25.2$ and $24.8{ }^{\circ} \mathrm{C}$ ) on settings I, II, and III, respectively, led to an increase in the equilibrium moisture content of these grains because as they are living bodies with a porous internal structure and with low thermal conductivity, which gives them a hygroscopicity characteristic, they are able to maintain constant heat and moisture changes to the environment through intergranular spaces in grains mass (MULTON, 1980).
Regarding grains quality, the electric conductivity test have shown good indicators of cell membrane integrity, since the higher the amounts of exudates ions into the grains, less intact will be the membranes, what reflects in the further deterioration of the grains (GOULART et al., 2007), and to have significant influence on the electrical conductivity tests, the water content of the grains should be adjusted to a range of between 10 and $17 \%$ (VIEIRA et al., 2002), which were values found in most treatments (Table 3).

It was observed that lowest values of electrical conductivity in the first evaluation period (30 days) occurred on setting I for the control, garlic and deltamethrin treatments, with deltamethrin being also statistically equal on setting II (Table 4). For the second evaluation period statistical equality was observed for garlic treatment, which showed lower values of electrical conductivity on settings I and III, followed by chlorpyrifos and deltamethrin on setting I.

Table 4. Electrical conductivity of grains at 30 and 60 days after the start of the treatment in the three studied settings. ${ }^{(1)}$

\begin{tabular}{|c|c|c|c|c|c|c|c|c|c|c|c|c|}
\hline \multirow[t]{3}{*}{ Insecticides } & \multicolumn{12}{|c|}{ Settings $^{(2)}$} \\
\hline & \multicolumn{6}{|c|}{30 days } & \multicolumn{6}{|c|}{60 days } \\
\hline & \multicolumn{2}{|c|}{ I } & \multicolumn{2}{|c|}{ II } & \multicolumn{2}{|c|}{ III } & \multicolumn{2}{|c|}{ I } & \multicolumn{2}{|c|}{ II } & \multicolumn{2}{|c|}{ III } \\
\hline Garlic & 38.5 & $\mathrm{aA}$ & 41.6 & $\mathrm{aAB}$ & 39.0 & $\mathrm{aA}$ & 60.7 & $\mathrm{aA}$ & 78.9 & $\mathrm{aAB}$ & 68.7 & $\mathrm{aA}$ \\
\hline Citronella & 60.0 & $\mathrm{aB}$ & 61.2 & $\mathrm{aC}$ & 79.9 & $\mathrm{aBC}$ & 92.9 & $\mathrm{aB}$ & 124.1 & $\mathrm{bC}$ & 118.6 & $\mathrm{bC}$ \\
\hline Chlorpyrifos & 43.4 & $\mathrm{aAB}$ & 53.3 & $\mathrm{abBC}$ & 67.6 & $\mathrm{bBC}$ & 57.5 & $\mathrm{aA}$ & 91.8 & bB & 87.7 & $\mathrm{bAB}$ \\
\hline Deltamethrin & 40.5 & $\mathrm{aA}$ & 34.0 & $\mathrm{aA}$ & 68.3 & $\mathrm{bBC}$ & 55.1 & $\mathrm{aA}$ & 55.7 & $\mathrm{aA}$ & 98.6 & $\mathrm{bABC}$ \\
\hline Neem & 47.8 & $\mathrm{aAB}$ & 40.4 & $\mathrm{aAB}$ & 74.5 & $\mathrm{bC}$ & 96.5 & $\mathrm{abB}$ & 82.2 & $\mathrm{aAB}$ & 116.0 & $\mathrm{bBC}$ \\
\hline Control & 37.4 & $\mathrm{aA}$ & 37.6 & $\mathrm{aAB}$ & 54.0 & bAB & 67.1 & $\mathrm{aAB}$ & 83.0 & $\mathrm{aAB}$ & 91.2 & $\mathrm{aABC}$ \\
\hline
\end{tabular}

${ }^{(1)}$ Means followed by the same letter, lowercase in lines or uppercase in columns, do not differ by Tukey test at 5\% probability. ${ }^{(2)} \mathrm{I}-$ Temperature and Relative Humidity: Setting; II - Temperature: Setting; Average humidity: 70\%; III - Average Temperature: $25.1^{\circ} \mathrm{C}$; Average humidity: $70 \%$. Mean values throughout the storage period.

It was noted that the increase of electrical conductivity was independent of the number of live insects (Table 2), including the possibility that natural insecticides have no insecticidal effect, but may have acted as repellents, as the integrity of the grains was maintained.
It was also noticed an increase in electrical conductivity values according to the storage period, which are results similar to those obtained by Alencar et al. (2008), who studied the quality of soybean in function of storage conditions and observed for a period of 180 days higher values of 
electric conductivity as the storage periods increased. The authors therefore inferred that higher levels of water contribute to the deterioration of the grains due to the denaturing of the cellular membrane.

\section{CONCLUSIONS}

Chlorpyrifos chemical insecticide offers $100 \%$ efficiency to control Sitophilus spp. Adults in all analyzed settings after 30 days of storage.

Deltamethrin had low Sitophilus zeamais control in the first assessment period, showing its efficiency in the subsequent period (60 days).
Plant insecticides offer low efficiency in the control of Sitophilus zeamais.

An increase in electrical conductivity and water content in the grains was observed according to the insects population growth.

\section{ACKNOWLEDGEMENTS}

To Coordenação de Aperfeiçoamento de Pessoal de Nível Superior for granting the master's scholarship.

RESUMO: O objetivo desse trabalho foi estudar o efeito inseticida de extratos vegetais aquosos e inseticidas químicos sob condições de armazenamento. O experimento foi realizado sob três condições de armazenamento. Os extratos aquosos foram obtidos pela adição dos pós vegetais de Allium sativum L, Azadirachta indica A. Juss. e Cymbopogon winterianum Jowitt. em água destilada na proporção de $5 \mathrm{~g}$ por $100 \mathrm{ml}$, e as dosagens dos inseticidas químicos foram de 0,04 e $0,15 \mathrm{ml} / 100 \mathrm{ml}$ de água para Deltametrina e Clorpirifós respectivamente. Os tratamentos foram adicionados aos grãos de milho acondicionados em recipientes de vidro de 2,5 L, misturados por agitação manual, e infestados com 20 adultos de Sitophilus zeamais não sexados. Os grãos ficaram armazenados durante 60 dias. Analisou-se aos 30 e 60 dias: contagem de insetos, teor de água nos grãos e condutividade elétrica. Os dados foram submetidos à analise de variância, e as médias comparadas pelo teste de Tukey a $5 \%$ de probabilidade. Aos 30 dias, observa-se eficiência dos inseticidas químicos no controle de Sitophilus zeamais nos três ambientes de armazenamento. Os extratos vegetais não são eficientes no controle dos insetos. O maior número de insetos elevam os valores de condutividade elétrica e umidade nos grãos.

PALAVRAS-CHAVE: Inseto. Temperatura. Umidade.

\section{REFERENCES}

AFONSO, A. P. S.; FARIA, J. L. C.; BOTTON, M.; LOECK, A. E. Controle de Sitophilus zeamais Mots., 1855 (Coleoptera: Curculionidae) com inseticidas empregados em fruteiras temperadas. Ciência Rural, v. 35, n. 2, p. 253-258, 2005. http://dx.doi.org/10.1590/S0103-84782005000200001

ALENCAR, E. R.; FARONI, L.R. D.; FILHO, A. F. L.; FERREIRA, L. G.; MENEGHITTI, M. R. Qualidade dos grãos de soja em função das condições de.Armazenamento. Engenharia na Agricultura, Viçosa, v. 16, n. 2, p. 155-166, 2008.

ALVES, W. M.; FARONI, L.R. D.; ALENCAR, E.R.; PAES, J.L.; Influência do inseto-praga sitophilus zeamais (motschulsky) (coleoptera-curculionidae) na taxa respiratória e na perda de matéria seca durante o armazenamento de milho. Engenharia na Agricultura, Viçosa, v. 16, n. 3, p. 260-269, 2008.

ANTUNES, E. G.; VIEBRANTZ, P. C.; GOTTARDI, R.; DIONELLO, R. G. Características físico-químicas de grãos de milho atacados por Sitophilus zeamais durante o armazenamento. Revista brasileira de engenharia agrícola e ambiental, Campina Grande, v. 15, n. 6, 2011.

ASAE. Moisture mesurament unground grain and seed. 39 ed. St. Joseph: American Society of Agricultural Engeenering: standarts, engeenering pratices and data, 1992. 404p. 
BRUNHEROTTO, R.; VENDRAMIM, J. D.; ORIANI, M. A. G. Efeito de genótipos de tomateiro e de extratos aquosos de folhas de Melia azedarach e de sementes de Azadirachta indica sobre Tuta absoluta (Meyrick) (Lepidoptera: Gelechiidae). Neotropical Entomology, v. 39, p. 748-791, 2010.

http://dx.doi.org/10.1590/S1519-566X2010000500018

CANEPPELE, M. A. B; ANDRADE, P. J.; SANTAELLA, A. G. Diferentes dosagens de pó inerte e temperaturas em milho Armazenado para controle de gorgulho-do-milho. Scientia Agraria, Curitiba, v. 11, n. 4, p. 343-347, 2010. http://dx.doi.org/10.5380/rsa.v11i4.18270

CANEPPELE, M. A. B; CANEPELLE, C.; LÁZZARI, F. A.; LÁZZARI, S. M. N. Correlation between the infestation level of Sitophilus zeamais Motschulsky, 1855 (Coleoptera, Curculionidae) and the quality factors of stored corn, Zea mays L. (Poaceae). Revista Brasileira de Entomologia, Curitiba, v. 47, n. 4, p. 625-630, 2003. http://dx.doi.org/10.1590/S0085-56262003000400015

CERUTI, F. C.; LAZZARI, S. M. N. Combination of diatomaceus Earth and poder deltamethrin for insect control in stored corn. Revista Brasileira de Entomologia, Curitiba, v. 49, n. 4, p. 580-583, 2005. http://dx.doi.org/10.1590/S0085-56262005000400020

COITINHO, R. L. B. C.; OLIVEIRA, J. V. GONDIM JÚNIOR, M. G. C.; CÂMARA. C. A. G. Atividade inseticida de óleos vegetais sobre Sitophilus zeamais Mots. (Coleoptera: Curculionidae) em milho armazenado. Revista Caatinga, Mossoró, v. 19, n. 2, p. 176-182, 2006.

CONAB - Acompanhamento da safra brasileira Safra 2011/2012 Décimo primeiro levantamento Agosto/2012.

http://www.conab.gov.br/OlalaCMS/uploads/arquivos/12_08_09_10_58_55_boletim_portugues_agosto_2012.p df. Acesso em: 21/08/2012.

FARONI, L. R. D.; BARBOSA, G. N. O.; SARTORI, M. A.; CARDOSO, F. S.; ALENCAR, E. R. Avaliação Qualitativa e Quantitativa do Milho em Diferentes Condições de Armazenamento. Engenharia na Agricultura, Viçosa, v. 13, n. 3, p. 193-201, 2005.

FERREIRA, F.A. Sistema SISVAR para análises estatísticas. Lavras: Universidade Federal de Lavras, 2000. Disponível em: <http://www.dex.ufla.br/ danielff/softwares.htm>. Acesso em: 13/06/2012.

GOULART, P. F. P.; ALVES, J. D.; CASTRO, E. M.; FRIES, D. D.; MAGALHÃES, M. M.; MELO, H. C. Aspectos histoquímicos e morfológicos de grãos de café de diferentes qualidades. Ciência Rural, Santa Maria, v. 37, n. 3, p. 662-666, 2007. http://dx.doi.org/10.1590/S0103-84782007000300010

GRABE, D. F. Report of the Seed Moisture Committee 1983-1986. Seed Science Technology., Zürich, v. 15, p. 451- 462, 1987.

GUIMARÃES, P. S. Desempenho de Híbridos Simples de Milho (Zea mays 1.) e Correlação entre Heterose e Divergência Genética entre as Linhagens Parentais. Campinas, 2007, 132p. Dissertação (Mestrado). Instituto Agronômico de Campinas.

LAHÓZ, A. C. Eficiência agronômica do Etofenprox no controle de Sitophilus zeamais Motsch., 1855 (Coleoptera: Curculionidae) em grãos armazenados de milho e a relação entre o seu ataque e a variação de umidade e atividade de água dos grãos. Piracicaba, 2008, 132p. Dissertação (Mestrado). Escola Superior de Agricultura Luiz de Queiroz, Universidade de São Paulo.

MULTON, J. Water vapor and heat transfers in grains silos and their consequences on storage. In: SHEJBAL, J. Controlled atmosphere storage of grains. Amsterdan, Elseiver, 1980. p. 399- 408. http://dx.doi.org/10.1016/B978-0-444-41939-2.50041-3 
PEREIRA, P. R. V. S.; PINTO JUNIOR, A. R.; FURIATTI, R.S. Eficiência de inseticidas no controle de Sitophilus oryzae (1.) (coleoptera: curculionidae) e rhyzopertha dominica (fab.) (coleoptera: bostrichidae) em cevada armazenada. Revista Acadêmica: Ciências agrárias e ambientais, Curitiba, v. 1, n. 3, p. 65-71, 2003.

SAMSON, P.R.; PARKER, J.; JONES, A.L. Comparative effect of grain moisture on the biological activity of protectants on stored corn. Journal of Economic Entomology, Lanham, v. 81, p. 949-954, 1988.

http://dx.doi.org/10.1093/jee/81.3.949

SILVA, A. A. L.; FARONI, L. R. D.; GUEDES, R. N. C.; MARTINS, J. H.; PIMENTEL, M. A. G.

Modelagem das perdas causadas por Sitophilus zeamais e Rhyzopertha dominica em trigo armazenado. Revista Brasileira de Engenharia Agrícola e Ambiental, Campina Grande, PB, v. 7, n. 2, p. 292-296, 2003. http://dx.doi.org/10.1590/S1415-43662003000200018

SMIDERLE, O. J; CICERO, S. M. Tratamento Inseticida e Qualidade de Sementes de Milho. Revista Brasileira de Sementes, v. 20, n. 2, p. 223-230, 1998. http://dx.doi.org/10.17801/0101-3122/rbs.v20n2p223230

TAVARES, M. A. G. C. Busca de compostos em Chenopodium spp. (Chenopodiaceae) com bioatividade em relação a pragas de grãos armazenados. Piracicaba, 2006, 111p. Tese (Doutorado) Escola Superior de Agricultura Luiz de Queiroz, Universidade de São Paulo

TAVARES, M. A. G. C; VENDRAMIM, J.D. Bioatividade da Erva-de-Santa-Maria, Chenopodium ambrosioides L., Sobre Sitophilus zeamais Mots. (Coleoptera: Curculionidae). Neotropical Entomology, v.34, n. 2, p. 319-323, 2005. http://dx.doi.org/10.1590/S1519-566X2005000200021

VIEIRA, R. D. Teste de condutividade elétrica. In : VIEIRA, R.D., CARVALHO, N.M. de. Testes de vigor em sementes. Jaboticabal : FUNEP, p. 103-132, 1994.

VIEIRA, R. D.; PENARIOL, A. L.; PERECIN, D.; PANOBIANCO, M. Condutividade elétrica e teor de água inicia das sementes de soja. Pesquisa Agropecuária Brasileira, Brasília, v. 37, n. 9, p. 1333-1338, 2002. http://dx.doi.org/10.1590/S0100-204X2002000900018 